\title{
THE UNEMPLOYED MID-CAREER ADULT: STRESSORS AND SUPPORT
}

\author{
LYNN RIBTON-TURNER \\ Department of Psychology \\ University of Johannesburg \\ GIDEON P DE BRUIN \\ gpdb@rau.ac.za \\ Department of Human Resource Management \\ University of Johannesburg
}

\begin{abstract}
The high rate of unemployment in South Africa is of national concern yet the experience of being unemployed is little understood; not enough is known about the unemployed condition in South Africa. In this study eight unemployed mid-career adults who had been out of work for longer than six months were interviewed in order to explore their lived experience. A qualitative methodology was used and from the extensive interview data, using qualitative content analysis, themes relating to the unemployed condition emerged. Results support, to a large degree, the existing literature and studies on the stressors impacting on the unemployed. This study offers additional insight into the support structures available for the unemployed adult.
\end{abstract}

Key words

Unemployment, retrenchment, self adjustment

Changes in the economy with information technology fostering a world-wide economy (Savickas, 2003) are extensively reported in the literature as well as the media and have resulted in the ongoing restructuring of business organisations. This has led to the retrenchment of millions of workers world-wide and statistics report high levels of global unemployment (Niles, Herr \& Hartung, 2002). Even with the economic recovery in the United States and Continental Europe unemployment is as high as was previously reported. Economists are calling the trend "the jobless recovery" (Foroohar \& Emerson, 2004) and unemployment is a feature which is expected to persist into the future. More and more workers feel insecure in a dangerous world (Hansen, 2003) and Altman and Post (1996) have called this period, "the age of anxiety". With work being relocated to countries in the East with its lower labour costs, workers in the West are required to compete for their jobs in a global market. Furthermore, the Western standards for productivity are bench-marked and compared with that of workers across the world. There is a perception that the new social contract between employer and employee is somewhere between immoral and amoral, with employees being treated merely as factors of production (Altman \& Post, 1996).

In this context mid-career adults are the group most often targeted for retrenchment. Flattened organisational structures have reduced the need for middle managers who are often midlife adults and significant cost savings are realised when higherearning employees are laid off (Greenhaus, Callanan \& Godshalk, 2000). Brewington and Nasser-McMillan (2000) report that it is the older, mid-career person who is at risk for unemployment.

It is the mid-life adult (usually forty years plus) who faces the daunting task of being forced to pursue a more 'protean' type career (Hall \& Mirvis, 1995; Hall \& Mirvis, 1996; Niles, Herr \& Hartung, 2002). This is a new exchange type relationship between employer and employee - the old relational contract (of reciprocal loyalty) is seldom evident. It is indeed an age of anxiety for the mid-career adult (Altman \& Post, 1996) who is susceptible to financial strains such as family responsibility and retirement planning (Greenhaus et al., 2000). Over the past decades these older workers have been socialised to believe that the organisation cared about its workers, displayed loyalty to employees and were party to the psychological or social contract (i.e. the employee was promised job security and advancement in return for hard work, loyalty and tenure); the unemployed today, in jobseeking, find that the relationship between employer and employee has changed dramatically.

A review of the literature suggests that stressors impacting on the unemployed mid-career person are mostly represented in two domains - there are the manifest (economic) and latent (experiential) consequences of unemployment (Brief, Konovsky, Goodwin \& Link, 1995). Brief et al. (1995) reported that economic deprivation (and not experiential deprivation) was a major contributor to stress and concluded that the economic aspects of unemployment have been neglected in unemployment research relative to the experiential aspects. This concurs with Sales' (1995) conclusion that researchers had paid little attention to the economic impact of unemployment, and that unemployment benefits in the form of financial aid were a crucial buffer for families after job loss. Turner (1995) agrees that the two categories of unemployment related stress most frequently identified are financial strain (economic consequence) and damage to sense of self (experiential consequence). Turner (1995) concludes that these two domains of stress, the emotional strain of financial deprivation and the stress of a more personal, non-material loss, are neither contradictory nor mutually exclusive.

The negative effects of unemployment are reported extensively in the literature, (Hanisch, 1999). Unemployment is one of the top ten traumatic life experiences (Spera, Buhrfeind \& Pennebaker, 1994) and the mentally distressing outcomes are reported by Caplan, Vinokur, Price and van Ryn (1989), Clark and Oswald (1994), Goldsmith, Veum and Darity, Jr. (1992), Hanisch (1999), Holmes and Rahe (1967), Turner (1995), Vinokur, Price and Caplan (1996) and Warr (1987). The psychological and physical symptoms reported by these authors are numerous, and include hostility, depression, anxiety, worry, strain, suicide attempts, alcohol abuse, anger, fear, violent behaviour, loneliness, social isolation and despair. Physical outcomes include headaches, stomach-aches, sleep problems, health deterioration and even death from stroke or heart disease (Vinokur et al., 1996). 
Wanberg, Watt and Rumsey (1996) report that most unemployment research has focussed on the impact job loss has on an individual's psychological and physical wellbeing; there have been few studies that have focussed on the support or support structures (financial or other) which ameliorate the negative effects of unemployment, (Hanisch, 1999). Jones (1991) reported that economic resources cushion the stresses of unemployment and act as a moderator of unemployment outcomes; others have confirmed this conclusion (Barling, 1990; Brief et al., 1995; Grant \& Barling, 1994; Shelton, 1985).

Several studies on job loss interventions, which aim to offer assistance to the unemployed, were reported by Hanisch (1999) and found to be effective, i.e. stress management was evaluated by Maysent and Spera (1995); disclosive writing by Spera et al. (1994); job club intervention by Rife and Belcher (1994) and JOBS intervention by Caplan, Vinokur and Price (1997). Hanisch (1999) suggests that activities and interventions which offer a wide range of activities to suit the individual or family (who are likely to have diverse needs) are likely to be the most effective.

\section{The Research Problem}

The high rate of unemployment in South Africa is of national concern yet the experience of being unemployed is little understood; not enough is known about the unemployed condition in South Africa. The purpose of this qualitative study was to understand and explore the lived experience of unemployed mid-career adults when they had been without work for an extended period of time. To explore the experience of the unemployed, the researcher decided to use phenomenological interviews with people who had been unemployed for six months or longer.

\section{RESEARCH METHODOLOGY}

\section{Research approach}

The researcher conducted interviews (unstructured with a schedule) with eight unemployed participants who had worked previously in the freight, shipping and logistics industries; seven were men and there was one woman. A trend was established after the eight interviews. In terms of racial group, five were "White" and two were "Indian"; all the participants had been out of work for six months or longer while two individuals had been without work for eighteen months. They were all at the mid-career stage and over forty years of age; in addition, they had all been employed gainfully in corporate life for the past twenty years of their careers and had been at a middle management level of seniority with their past companies. The participants were purposively selected.

In the interviews the participants were asked to tell their story of being unemployed and to share their most critical experiences of the past months. The interview method was a one-on-one, faceto-face interview, using open-ended questions (Creswell, 2003); it was an unstructured format with a schedule (Schurink, 1998); and a feminine (Oakley, 1981) and creative stance (Douglas, 1985) was taken, at times, in the interview. The study followed a constructivist approach since the aim of the enquiry was understanding, and the interview type was selected to illicit rich and abundant data.

In following a phenomenological method, ensuring trustworthiness became blurred, since truth is subjective and hence not available when considered from an external viewpoint. In following, to some degree, Guba and Lincoln's (1989, 1994, 2000) criteria for judging the "goodness" of a research enquiry, three follow up interviews with the participants were arranged, each was about one and a half hours, and the content of the participants' transcripts were confirmed.

The interviews were audiotaped, transcribed and analysed using qualitative content analysis. Sub-themes and then the main themes of this study emerged from the data using largely inductive reasoning (Creswell, 2003). A co-coder read the transcripts and found saturation of the data after the sixth participant's transcript. Her themes and sub-themes reflected those of the researcher. No additional themes or sub-themes emerged from her analysis.

In summary, the data was reduced and reformatted, it was interpreted, and it moved from the field (interview) to the text to the reader, each step involving a reflexive process. The interviews and the analysis of the data resulted in sub-themes, these were looked at for duplication and overlap and then reduced to fifteen sub-themes and four major themes.

\section{RESULTS}

In considering the stressors and support that hindered or helped the unemployed participant, the results of Theme 1 will be discussed in this paper; all fifteen sub-themes identified in the research are shown for interest (see Table 1).

\section{TABLE 1}

MAJOR AND SUB-THEMES OF THE UNEMPLOYMENT EXPERIENCE

\begin{tabular}{|c|c|}
\hline MAJOR THEME & SUB-THEME \\
\hline $\begin{array}{l}\text { 1. Unemployment is experienced } \\
\text { as a crisis of survival, impacting } \\
\text { across all levels of human } \\
\text { functioning }\end{array}$ & $\begin{array}{l}\text { 4.1 Financial impact - economic } \\
\text { survival } \\
\text { 4.2 Psychological issues - stress, } \\
\text { distress and the experience of loss } \\
\text { 4.3 Damage to sense of self } \\
\text { 4.4 Changes in physical health } \\
\text { 4.5 Family impact: Role and lifestyle } \\
\text { changes }\end{array}$ \\
\hline $\begin{array}{l}\text { 2. Coping behaviour - resources } \\
\text { available (self and others) and } \\
\text { coping strategies }\end{array}$ & $\begin{array}{l}\text { 4.6 Coping resources, self } \\
4.7 \text { Coping resources, family and } \\
\text { community support }\end{array}$ \\
\hline
\end{tabular}

3. Contextual issues - South African employment conditions, age bias, work-place and social change

4.10 Unemployment in South Africa 4.11 Mid-career issues and the older worker

4.12 Changes in the corporate world following global competitiveness: social change

4. The participants' recommendations to other unemployed adults to facilitate survival (messages of caution and encouragement)

4.1 Lessons learnt, reflections on the meaning of work

4.2 View of the future

4.3 The message to others experiencing job loss

All of the participants experienced to a greater or lesser extent the impact of the sub-themes of Theme 1 . After some months without work (six months or longer), unemployment is experienced as a time of severe or acute stress or distress and for all participants, it is a period of crisis, financial struggle and one of an attempt at survival. It is described as 'devastating', 'a time of panic attacks', 'a worrying time', 'a time of black depression', 'a period of shock', 'it's a scary experience', 'a critical time', 'a period of frustration, exhaustion and numbness during which time I seriously considered shooting myself.

In overview, the results demonstrated that the impact of job loss and unemployment reverberates across all the levels of human functioning, the physical, emotional, mental and spiritual domains. In addition, it devastates family and social life and financial strain was identified as the key stressor through the period of unemployment. The participants' stories communicated their financial fears as well as feelings of being totally worthless, the emotional states of anxiety and depression 


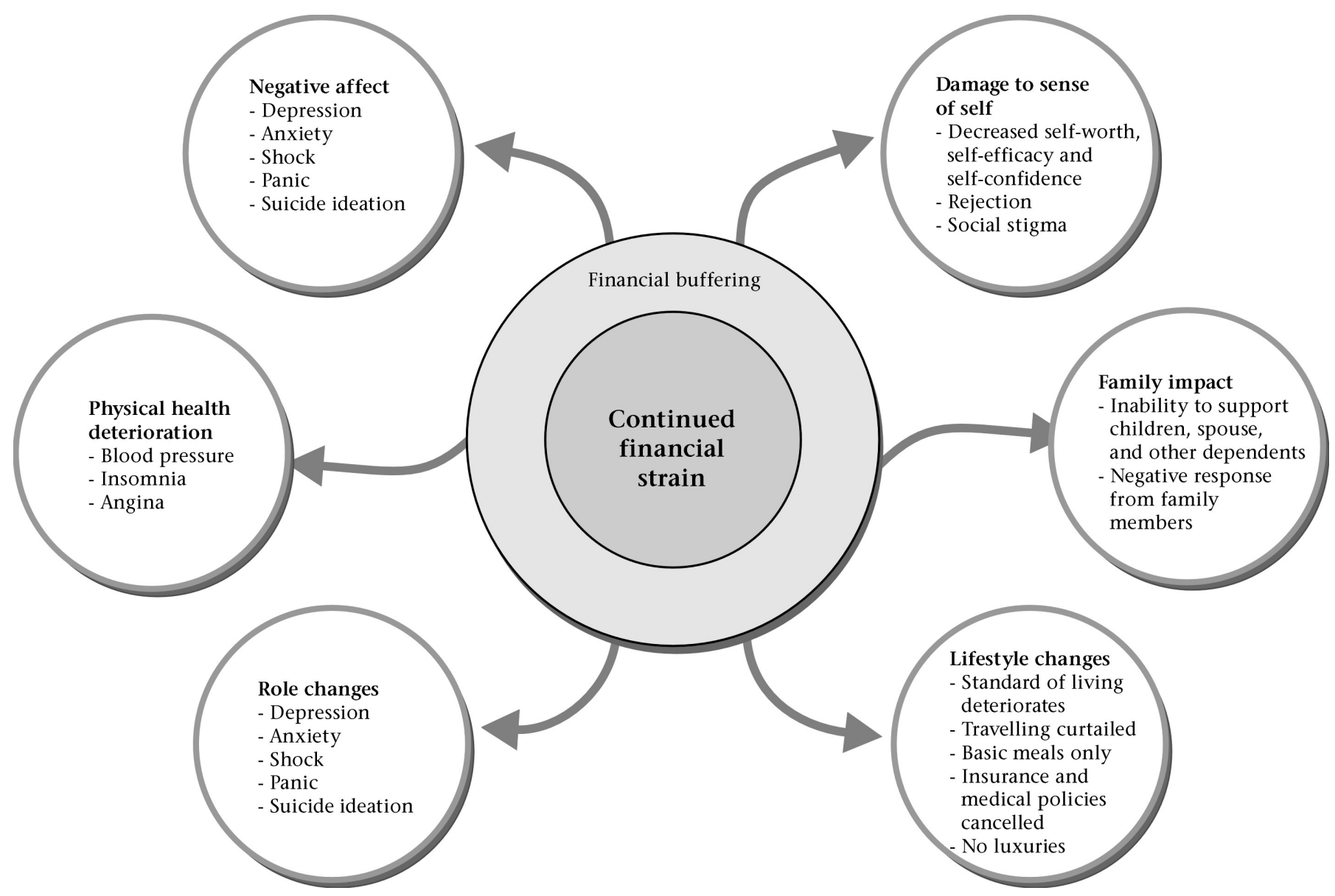

Figure 1:. Impact of Continued Financial Strain on the Unemployed Adult

and physical symptoms of stress such as elevated blood pressure, eczema and sleeplessness. Unemployment, after a period of time, is described as undermining all aspects of one's life and functioning.

\section{STRESSORS}

In the interviews all eight participants spoke without hesitation about financial strain as the most chronic stressor. Figure 1 illustrates the consequence of financial strain for the unemployed person across all levels of functioning.

Financial buffers which took the form of savings, pension fund payouts or retrenchment packages eased the burden of dealing with the daily financial requirements without the monthly salary. The first sub-theme to be discussed is that of "financial impact" and the participants' quotations are reported.

Sub-theme: Financial impact - economic survival

Each participant spoke extensively about the impact of the lack of finances, "Greatest fear - fear of financial insecurity, financial imbalance", "Most difficult change... to try and find the finances to stay alive, to survive"; "Not having finances also resulted in me not even being able to have a home and food and petrol and basic necessities". "What we can have and do becomes severely restricted and limited", "I have got to put food on the table and the bills have to be paid and it's not easy. I think up till now we've been relatively lucky to still eat every day and we go to sleep every night and just keep on trying all the options that you have open to you."

One participant relied on a friend to give her cash to buy simple meals "... lent me money constantly - she would just give me money". "I didn't have money to even put in the pay phone if I got an answering machine I could have shot myself because with R1-00 I can buy something for dinner, I can buy some carrots or buy some fruit". One participant "spoiled" himself with a hamburger and commented how such a simple meal can become "wonderful" - "The pastor gave me R400-00 - I don't know who it came from - with that R400-00 I blessed more people, I was past trying to save myself: I kept my little bit and I had my hamburger and it was wonderful and chips".

Lack of ready cash for fuel meant that travelling was restricted “... You just limit your driving around ... when you don't have money for petrol" . "If I get an interview I've got to depend on people or find my way to get there either by taxi or train or whatever, but I've got to find a job". Family members felt the impact of the lack of funds; "I've got to put her (daughter) in a government school with 42 kids in her class and I don't know how she is going to cope ... you realise that finances have their place, certainly", "I battled looking them in the eye because obviously I couldn't pay maintenance and we had to explain it to them (the children)", "They said (children) Dad if you end up on the street we will visit you and sit with you in the street".

The lack of finances and the economic insecurity was said to cause worry, anxiety, changed sleep patterns, depression and feelings of being scared for the future, "Financial concerns ... you know, it becomes a 'what if' it runs out". Many of the participants reported their fear for the future, what would happen if he or she could not find a job and the funds were to run out "I prayed many times and said to the Lord what happens if the money is finished, that's what my stress is. I need a job before my money finishes". "You know you have got all these commitments and you've got to sort of live up to them - you don't want ... to take out these little boards like people on street corners - Please God help". Being unemployed was described by all the participants as a highly emotional period of their lives and this is elaborated on in Sub-Theme - Psychological issues. 
Sub-theme: Psychological issues - stress, distress and the experience of loss

The unemployed period and the transition from gainful, responsible, challenging and secure employment to being without work is described by all participants as not only "an incredibly stressful time" but also a highly emotional period of their life. Words used by the interviewees to describe their emotional state through this period are:

"Feeling quite isolated", "Anger", "This has been a dramatic shock", "A worrying time - that everything would fall apart", "I am emotionally and physically not well", "When I am on my own I go and resort to drinking", "On occasion one can sink into a fairly black depression", "I was too depressed that I really was like numb, that's possibly the feeling ... I was so exhausted I wanted to just sleep", "I said to myself, I wonder if I am depressed because I don't know what depressed looks like - "I feel if it carries on too long and I isolate myself too much I'm going to become a hermit, I'll be too scared to socialise with people", "I feel that I'm walking down a dark passage ... I don't see a light at the moment", "My greatest fear at the moment is dying before I can succeed", "I think that it is an emotional experience...the dark hour and the main thing is you've got to keep up hope" "Then I started like having a panic attack ... then I started getting anxious".

Experiences of stress were reported by all of the participants without exception. Physical symptoms were described such as "My feet - became dry and itchy - they were swollen and the skin cracked"; "Waking up with terrible pains in the neck and shoulders, the Doctor gave me a tranquiliser just to make me sleep". Almost all individuals spoke of depression, lack of energy and changed sleep patterns "Oh ja, they medicated me ... take the edge off anxiety and depression"; "I stay awake the entire night - your mind is not at rest"; "I've been getting heavy sets of depression".

Suicide ideation arose for some of the interviewees and it was described as "That (suicide) did cross my mid, yes I did go through a bad patch, if I had a gun then I would have taken it"; "Ja, I looked at the burglar bars and I wondered if I would tie a rope there if it would hold me"; "I think if I was alone and in an unfamiliar country I would seriously have considered shooting myself"; "Life wasn't worth living I just didn't have the courage to do anything about it ... I couldn't imagine putting a gun to my head, I can't bear swallowing tablets ... I can't imagine gassing myself ... I couldn't imagine slitting my wrists because of the blood ... after shoving all those tablets down your throat, I mean puking them up and not winning, you know not succeeding". Not one person in the research group had visited a psychologist or a counsellor for help. Most participants believed that counselling could certainly be of assistance; others commented that the cost would have been unaffordable and others had just not thought about it, but had rather visited their medical practitioner. Damage to the sense of self was spoken about extensively by all the participants, this is elaborated upon in the following sub-theme, Damage to the sense of self.

Sub-theme: Damage to the sense of self

The participants reported that there are dramatic changes that take place with regards to self-esteem and self-worth when an individual is without work. Being out of work is described as "an unbelievable attack on my self worth"; "being unemployed one is treated like a leper"; "you become a social pariah when unemployed"; "after three months of unemployment one feels useless there is nowhere to go"; "you become less important to your wife and family"; "not being the role model or breadwinner you are not an asset just a liability"; "There are all these people going to work and you are just not good enough"; "I think one is inclined to question one's self worth when you raise doubts about yourself - why has this happened to me, look what you've done".

It was reported by many of the participants that initially the feeling of worthlessness related to one's value in the workplace "Feelings of not being wanted in the workplace"; "I think my economic value, my commercial value in my own mind is under great question". This participant spoke of himself as partly the 'economic man' and that his commercial value was under question since he couldn't find a job; however, his overall self worth was cemented by people who love him, as well as the Lord, and that he didn't question.

The change in self esteem also impinges on the individual's confidence to interact with friends or acquaintances "Irrespective of what money you have, your self-worth goes down if you are unemployed. You have no conversation, you have no reason to participate"; "I have far less of an opinion of myself"; "The period has been one of a loss of self confidence". Being rejected after interviews created a downward spiral in the individual's self esteem, this was exacerbated when there were a series of unsuccessful job interviews. "Started to get anxiety about it (finding a job) - my God am I actually employable"; after repeated rejection the early optimism of re-employment and the idea that one would return promptly to the workplace began to fade "You start to question yourself - yes, you start to question your professional acumen".

Status was important to some of the participants. One participant felt that in the corporate world a man is a hunter and the individual without an income or a job is no good for anything, not even any good to mate with. Within a male group he saw that the greeting dance of men was, "what do you do?"; then you would be judged accordingly on your profession or your work and that is your perceived worth. He continued that the male world has moved from a hierarchy driven by physical strength to a power play based on financial strength. All the participants reported changes in physical health and the Sub-theme, Changes in physical health elaborates on their experiences.

Sub-theme: Changes in physical health

Almost all of the participants reported physical symptoms of stress. Physical symptoms reported were changes in blood pressure, swollen feet, eczema on hands and feet, muscle cramps and contractions, chronic pain, headaches and chronic fatigue syndrome. The last sub-theme describes how the family was disturbed by the participants' unemployed position and the lifestyle and standard of living needed to be adjusted.

\section{Sub-theme: Family impact, role and lifestyle changes}

The participants with children in the home suffered greatly through the stress of the impact on their family "I couldn't pay maintenance and we had to explain my situation to them". Maintenance payments could no longer be made to divorced spouses or elderly family members who were being supported "Ja, dramatically effected, my mom lives off a government pension and relies $100 \%$ on me. She has been effected quite traumatically". "How do I say to my child, look I have money but I cannot give it to you because I am not sure when I will find a job". Two of the fathers saw that their role in the family was questioned and that they were no longer seen as the head of the household or worthy to be consulted on various matters, but were treated with pity or contempt "Before you hosted dinners and luncheons and you end up going to them (children), it changes the social setting".

Spouses were also adversely affected being required to carry the interim financial burden or find a job even if they had never worked previously. One respondent's wife who had never been employed during her marriage, in the face of uncertainties, decided to leave the marriage and marry a family friend. Dependent elderly parents were likewise seriously affected since they were relying to a large extent on the contribution from a daughter or son. Another participant mentioned that the family impact was 'devastating', "for family life it is devastating"; "it curtails a lot of normal activity, what can be provided and what can't, essentials only". Any unexpected problems from children became exceptionally difficult to resolve under these stressful circumstances. "You know my one daughter went off the rails, ... she took drugs and then landed back at home with a nervous breakdown and R30, 000 worth of debt". 


\section{SUPPORT STRUCTURES}

The areas of support that are discussed are financial buffering, psychotherapy services, medical assistance, spiritual or religious conviction, social support and, finally, the companionship with pets or animals.

\section{Financial Buffering}

The eight participants did not have access to state unemployment funds and therefore needed to find private means for their financial requirements. Four of the eight participants at the time of the interview had no savings to draw on; these individuals needed to either sell their motor vehicles or have them repossessed. They accepted contributions from friends and family towards mortgage bond payments or rental costs and struggled to put food on the table. The other four unemployed participants had limited savings and their persistent fear was "what if the money runs out before I find employment?" Two participants had no alternative but to downscale their lifestyle by selling their property and purchasing smaller homes.

\section{Psychotherapy Services}

The participants agreed that they would have used the services of a psychotherapist or counsellor; however, funds were not readily available, after six months or longer of unemployment none of the participants were members of a medical aid scheme. In attempting to cope with their emotional distress, some individuals had a good friend or mentor to communicate with. A few participants tended to release their emotions either with an occasional binge of drinking alcohol or outbursts of anger "the other day I shouted at my wife"; "I went to the shops bought myself a bottle and just drank".

Medical Practitioner - health services

Five of the participants visited a medical doctor and family members paid for the visits. All of the respondents needed to deal with depression; this was addressed either with medication from their doctor, "oh ja, they medicated me for that, the medication takes the edge off", or they would withdraw into solitude or lengthy sleeping periods of up to 12 hours a day. "I used to sleep a lot and then wake at the normal sleeping time which throws your cycle out". Other participants visited their doctor to deal with angina, blood pressure irregularities, eczema or muscle spasm.

\section{Spiritual/Religious Conviction}

The participants differed in the importance of spirituality in their lives, but almost all individuals found this to be a key element of support in helping them to cope on a day to day basis and to retain hope "there has definitely been a higher level of commitment to my spiritual world"; "I am looking to God that's where my strength is coming from, that's where my hope is ..."; "its more faith and hope that is keeping me going", "So I must leave it (my life) with God ... and so the winter must end". Many read the Bible daily discovering new verses that gave them insight to their difficulties "God has opened my eyes to many things". The spiritual traditions of the participants differed with one candidate doing his prayers at the temple "I do my prayers every morning and I ask God for his full support", another ministering to members of his parish, another reading the Bible and meeting frequently with church members "thank goodness I'm an elder at the church and I minister quite a lot"; "on Fridays we have a members fellowship".

Almost all commented that they had become closer to a larger power in life or that God had become more real to them. All found support from Jesus, the Higher Power or that God is 'awesome' "Oh yes, if you have your God thing then I think you have support". All the individuals commented that there were lessons to be learned, that they didn't necessarily understand the reasons for their crisis, but that they accepted what they needed to go through "God will take you through it".

\section{Social Support}

Support from family, friends or community appears to be an important mediating factor in the ability to cope and in the control of stress for the out-of-work person. The unemployed individuals interviewed who had extended family support experienced a more positive environment in which to cope with their distress "Oh yes, I have a wonderful family"; "Not only my wife and my children but also brothers, sisters were really supportive of me"; "When I met my wife she was a great boost for me". Not all participants received support from family; "She (the wife) was moving on, she certainly wasn't supportive at those times". Fathers appeared to be concerned over the change in their relationships with their children "We went to our parents for a family discussion with the 'head', now I am a guest". It is not always the family who offer the main support, financial or emotional, as one participant mentioned "if it wasn't for the support from friends, I would feel totally alienated".

Two of the participants commented on the isolation that would be experienced if they were in a foreign country without familiar contacts, and how the feeling of alienation would be exacerbated without support from family. One commented that one could then think about suicide "I think if I was alone and in an unfamiliar country with no support I would seriously have considered shooting myself". One participant discussed close ties with his mother as "my mother doesn't interfere, she was wonderful cause I could just go there and she never said anything". The extended family support is appreciated as "family involvement, I think that is what really keeps you going". In terms of social life, many friends proved to be a disappointment, "they don't phone you; the unemployed are treated like lepers".

\section{Companionship with animals}

The companionship with animals was found to be very therapeutic for most individuals. "They (sheep and goats) know what time you are coming, they come and eat from your hand ... it is very exciting I must say". Another found companionship with his two Jack Russell dogs; he repeated that they had given him intense pleasure "The only thing that has been wonderful to me is animals ... they are very comforting just to be able to talk to and have around". Another, enjoyed interacting with his two lovebirds, feeding them and allowing them to fly around the apartment "They are real characters I can sit and watch them for hours".

Figure 2 clarifies in pictorial form the stressors and support experienced by the participants. The stressors include financial strain, psychological, mental and physical distress, confusion resulting from changes in the work environment, spiritual questioning, diminishing sense of self-worth and the inability to fulfil family obligations. Support was in the form of services of a medical doctor; financial buffering in the form of savings or retrenchment packages; spiritual or religious practices; family care (for a few participants) and the companionship of a close mentor or friend was meaningful for all the individuals.

In summary, financial strain was without question mentioned as the most chronic stressor. Declining self-efficacy beliefs and a deteriorating sense of self-worth was referred to as another debilitating source of stress. When considering the support structure(s) of the unemployed, spiritual support from the pastor and religious (or spiritual) beliefs were extremely important to maintain hope for the future. Most of the participants identified a close friend or relative, often not immediate family, as a source of strength, and a few of the unemployed found that their spouse offered support - others experienced undermining from their partner. Medical practitioners were able to offer some relief for the symptoms of stress for those who had access to a doctor. That concludes the results of this study relevant to the stressors and support experienced by the unemployed. 


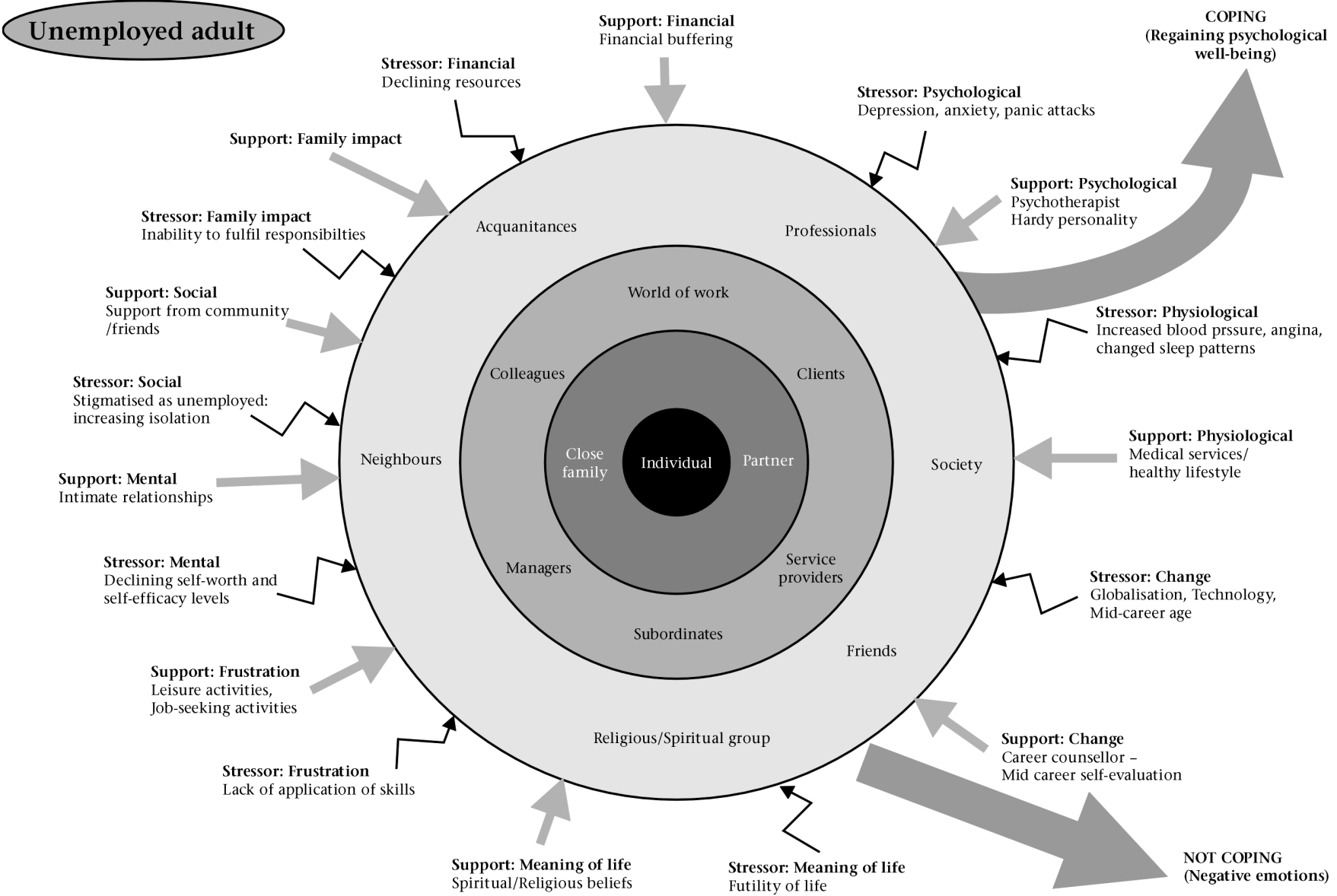

Figure 2: The unemployed adult: Stressors and support

\section{DISCUSSION}

From the results and findings of this study it is clear that economic deprivation becomes a central issue creating trauma and stress in the lives of the unemployed. Sales (1995) and Brief et al. (1995) concluded that the economic aspects of unemployment had been neglected in research on the unemployed relative to the experiential issues. The length of time in unemployment exacerbates the experience of stress across all levels of functioning (Brief et al., 1995). The participants with even limited financial resources interacted socially, having the means to participate, and used hobbies, sporting and family activities to structure their time. The unemployed participants who, after an extended period of time without work, were virtually without resources to support the usual requirements of living i.e. transport, shelter, food or family responsibility, became more isolated and withdrew from social interaction.

The psychological aspects of unemployment referred to most frequently by the participants were a declining self-esteem and a reduction in the belief of their self-efficacy. The first few months after job loss was approached as a holiday period and over the months, with repeated rejection following job interviews, self confidence, self-esteem, and belief in their selfefficacy declined. Hanish (1999) suggests that for research on the unemployed state to be meaningful, the length of time without work or since job loss needs clarification. Other stressors reported by the participants included the physical symptoms of stress such as angina, sleeplessness and eczema, and psychological symptoms such as depression, anxiety, suicide ideation and the inability to provide for family responsibilities.

Key contextual issues described by the participants as stressors were age bias (stereotypes of older workers), racial group (white men felt discriminated against due to South African black economic equity legislation); the high level of unemployment in South Africa (37\% reported by Makgetla, 2001); changes in the world of work (the change in the psychological contract between employee and employer i.e. the decline in loyalty and respect in the relationship) and the workplace demand for tertiaryqualified youth with high energy levels. The unemployed person was confused and unsure how to respond to these new work place demands and how to make the transition from organisational dependency to the new requirement of an independent (self-guiding) "protean" career.

In terms of support for the unemployed adults - their spiritual or religious life became pivotal to maintain hope and continue day after day into the future. Some of these participants interacted socially with church members or their religious group and did not feel socially stigmatised as they did in other circles, and there was no cost to participate.

Only a half of the participants received emotional support from close family and/or spouse. Children were seen to challenge their fathers for not being able to secure work and this led to questions of identity as the 'father figure' or the role of provider and resulted in distress. A mentor or friend outside of the immediate family was a source of strength for all the participants; with this person they shared their fears and concerns. Household pets became a source of companionship during the long days often spent in the home.

The services of advisors and professional people were called upon if resources were available, such as a family doctor or financial advisor. Financial support was not available for this group through unemployment benefits. A few of the participants received retrenchment payouts, but after six months most of these funds had been utilised. The unemployed person without private funds in South Africa has no choice but 
to rely on family and friends for finances for the basic necessities. Outplacement services were not offered and the participants explained that they did not have the funds or medical aid membership to seek support from psychologists, family counsellors or career counselling professionals.

In considering the results of other studies on the unemployed by Archer and Rhodes (1995), Leana and Feldman (1988), and Vinokur et al. (1996), findings of this research are not materially different; however, the emphasis differs. This study highlights the economic deprivation of the unemployed as does Brief et al. (1995); Darity Jnr. and Goldsmith (1996); and Sales (1995), whereas most other studies focus on the psychological aspects of unemployment. In reading the literature there is little reported on the support structures to assist the unemployed; Hanish (1999) does, however, refer to job loss interventions and their successful outcomes. Spiritual or religious concerns were not evident in the literature on the unemployed even though a holistic approach to career concerns (Hansen, 2003; Niles et al., 2002; Savickas, 2003) including body, mind and spirit is now advocated.

\section{LIMITATIONS AND RECOMMENDATIONS}

This qualitative study generated rich data on the experience of the unemployed mid-career person, however, the limitations of this study need to be considered when assessing the findings. The most obvious omission in a study conducted in South Africa is that of African participants. In purposely selecting the sample the researcher made an attempt to find African individuals and it was a difficult task. Within the freight industry there is a large representation of Indian and White men and women in all positions including middle management, but there is a scarcity of African men or women in middle management. Even ten years after political change there is an under-representation of Africans in middle management in this industry. The sample is, however, representative of the major group in the South African freight industry experiencing retrenchment and job loss (White mid-career men). The variables of race, gender and occupational group could have been better addressed; in terms of gender, only one woman was used in the sample. As far as occupational group is concerned, all participants were drawn from the same industry; a sample taken from broader industry segments may have resulted in more widely applicable findings.

In terms of further research arising from this study, there were interesting findings in the changes in the unemployment experience over time. Firstly, most of the participants in later follow-up interviews refuted the idea that shock followed the announcement of retrenchment. They all commented that in South Africa there is, through legislation, a general staff warning sometime ahead of individual communication about retrenchment. This means that the current literature on the job loss cycle and its stages should be re-examined; in the South African workplace retrenchment is not a new phenomenon and in this age of anxiety (Hansen, 2003), retrenchment, downsizing and mergers are expected.

Another point of interest in the unemployment experience over time was a description of the immediate change in mood when employment was found - it was described as an empowering return to an "old" but "new" reality. A potential area for further research would be to explore if the re-employed person returns to his or her previous state of functioning or does the experience of ongoing stress scar the person? Does the mid-life adult return to his or her emotional and mental state prior to this chronic experience of unemployment or as with Selye's general adaption syndrome (1976) does he or she not recover fully from the psychological disintegration, can the damage be repaired and his or her resources reorganised?

\section{REFERENCES}

Altman, B.W., \& Post, J.E. (1996). Beyond the social contract. In D.T. Hall and Associates (Eds.), The career is dead (pp. 46-71). San Francisco: Jossey-Bass Publishers.

Archer, J., \& Rhodes, V. (1995). A longitudinal study of job loss in relation to the grief process. Journal of Community \& Applied Social Psychology, 5, 183-188.

Barling, J. (1990). Employment, stress and family functioning. New York: Wiley.

Brewington, J.O., \& Nasser-McMillan, S. (2000). Older adults: Work related issues and implications for counselling. Career Development Quarterly, 49, 2-14.

Brief, A.P., Konovsky, M.A., Goodwin, R., \& Link, K. (1995). Inferring the meaning of work from the effects of unemployment. Journal of Applied Social Psychology, 25, 693711.

Caplan, R.D., Vinokur, A.D., \& Price, R.H. (1997). From job loss to re-employment: Field experiments in prevention-focussed coping. In G.W. Albel \& T.P. Gullotta (Eds.), Primary prevention works. Thousand Oaks, CA: Sage.

Caplan, R.D., Vinokur, A.D., Price, R.H., \& van Ryn, M. (1989). Job seeking, re-employment, and mental health: A randomized field experiment in coping with job loss. Journal of Applied Psychology, 74, 759-769.

Clark, A.E., \& Oswald, A.J. (1994). Unhappiness and unemployment. The Economic Journal, 104, 648-659.

Creswell, J.W. (2003). Research design: Qualitative, quantitative and mixed method approaches (2nd ed.) London: Sage.

Darity, W. Jnr., \& Goldsmith, A.G. (1996). Social psychology, unemployment, and macro economics. Journal of Economic Perspective, 10, 121-140.

Douglas, J.D. (1985). Creative interviewing. Beverly Hills, CA: Sage

Foroohar, R., \& Emerson, T. (2004, August 23). A heavy burden. Newsweek, 33-37.

Goldsmith, A.H., Veum, J.R., \& Darity, W., Jnr. (1992). Social psychology, unemployment exposure and equilibrium unemployment. Journal of Economic Psychology, 13 (3), 449-471.

Grant, S., \& Barling, J. (1994). Linking unemployment experiences, depressive symptoms and marital functioning. A mediational model. In G.P. Keita \& J.J. Hurrell, Jnr. (Eds.), Job stress in a changing workforce: investigating gender, diversity and family issues (pp. 311-327). Washington, DC: American Psychological Association.

Greenhaus, J.H., Callanan, G.A., \& Godshalk, V.M. (2000). Career management. New York: The Dryden Press.

Guba, E.G., \& Lincoln, Y.S. (1989). Fourth generation evaluation. Newbury Park, CA: Sage.

Guba, E.G., \& Lincoln, Y.S. (1994). Competing paradigms in qualitative research. In N.K. Denzin \& Y.S. Lincoln (Eds.), Handbook of qualitative research (First ed.) (pp. 105-117). London: Sage.

Guba, E.G., \& Lincoln, Y.S. (2000). Paradigmatic controversies, contradictions, and emerging influences. In N.K. Denzin \& Y.S. Lincoln (Eds.), Handbook of qualitative research (2nd ed.) (pp. 163-233). London: Sage.

Hall, D.T., \& Mirvis, P.H. (1995). The new career contract: Developing the whole person at midlife and beyond. Journal of Vocational Behavior, 47, 269-289.

Hall, D.T., \& Mirvis, P.H. (1996). The new protean career: Psychological success and the path with a heart. In D.T. Hall $\&$ Associates (Eds.), The career is dead, long live the career (pp. 15-45). San Francisco: Jossey-Bass Publishers.

Hanisch, K.A. (1999). Job loss and unemployment research from 1994-1998. A review and recommendations for research and intervention. Journal of Vocational Behavior, 55, 188-220.

Hansen, L.S. (2003). Career counsellors as advocates and change agents for equality. Career Development Quarterly, 52, (1), 43-51.

Holmes, D.S., \& Rahe, R.H. (1967). The social readjustment rating scale. Journal of Psychosomatic Research, 11, 213-218. 
Jones, L. (1991). Specifying the temporal relationship between job loss and consequences: Implications for service delivery. Journal of Applied Social Science, 16, 37-62.

Leana, C.R., \& Feldman, D.C. (1988). Individual responses to job loss: Perceptions, reactions, and coping behaviors. Journal of Management, 14 (3), 375 - 389.

Makgetla, N. (2001). So how bad is unemployment really? S.A. Labour Bulletin, 25, (2),16-22.

Maysent, M., \& Spera, S. (1995). Coping with job loss and career stress: Effectiveness of stress management training with outplaced employees. In L.R. Murphy, J.J. Hurrell, S.L. Sauter, \& G.P. Keita (Eds.), Job stress intervention (pp. 159 - 170). Washington, DC: American Psychological Association.

Niles, S.G., Herr, E.L., \& Hartung, P.J. (2002). Adult career concerns in contemporary society. In S.G. Niles (Ed.), Adult career development (pp. 2-18). National Career Development Association.

Oakley, A. (1981). Interviewing woman: A contradiction in terms. In H. Roberts (Ed.). Doing feminist research (pp. 30-61). London: Routledge \& Kegan Paul.

Rife, J.C., \& Belcher, J.R. (1994). Assisting unemployed older workers to become re-employed. An experimental evaluation. Research on Social Work Practice, 4, 3-13.

Sales, E. (1995). Surviving unemployment: Economic resources and job loss duration in blue-collar households. Social Work, $40,483-494$.
Savickas, M.L. (2003). Advancing the career counselling profession: Objectives and strategies for the next decade. Career Development Quarterly, 52, 87-96.

Schurink, E.M. (1998). The methodology of unstructured face to face interviewing. In A.S. de Vos (Ed.), Research at grass roots (pp. 297-312). Pretoria: Van Schaik.

Selye, H. (1976). The stress of life (2nd ed.). New York: McGrawHill.

Shelton, B. (1985). The social and psychological impact of unemployment. Journal of Employment Counselling, 22, 18-22.

Spera, S.P., Buhrfeind, E.D., \& Pennebaker, J.W. (1994). Expressive writing and coping with job loss. Academy of Management Journal, 37, 722-733.

Turner, J.B. (1995). Economic context and the health effects of unemployment. Journal of Health and Social Behavior, 36, 213-239.

Vinokur, A.D., Price, R.H., \& Caplan, R.D. (1996). Hard times and hurtful partners: How financial strain affects depression and relationship satisfaction of unemployed persons and their spouses. Journal of Personality and Social Psychology, 71, 166-179.

Wanberg, C.R., Watt, J.D., \& Rumsey, D.J. (1996). Individuals without jobs: An empirical study of job-seeking behavior and reemployment. Journal of Applied Psychology, 81, 76 - 87.

Warr, P. (1987). Work, unemployment and mental health. New York: Oxford. 